\title{
Teams, Team Motivation, and the Theory of the Firm
}

\author{
Foss, Nicolai J.; Lindenberg, Siegwart
}

Document Version

Final published version

Publication date:

2011

\section{License \\ CC BY-NC-ND}

Citation for published version (APA):

Foss, N. J., \& Lindenberg, S. (2011). Teams, Team Motivation, and the Theory of the Firm. Institut for Strategic Management and Globalization. SMG Working Paper No. 11/2011

Link to publication in CBS Research Portal

\section{General rights}

Copyright and moral rights for the publications made accessible in the public portal are retained by the authors and/or other copyright owners and it is a condition of accessing publications that users recognise and abide by the legal requirements associated with these rights.

\section{Take down policy}

If you believe that this document breaches copyright please contact us (research.lib@cbs.dk) providing details, and we will remove access to the work immediately and investigate your claim. 
TEAMS, TEAM MOTIVATION, AND THE THEORY OF THE FIRM

\author{
Nicolai J Foss \\ Department of Strategic Management and Globalization \\ Copenhagen Business School; Kilen 14, $2^{\text {nd }} \mathrm{fl}$. \\ 2000 Frederiksberg; Denmark \\ njf.smg@cbs.dk \\ and \\ Department of Strategy and Management \\ Norwegian School of Economics and Business Administration \\ Breiviksveien 40, N-5045 \\ Bergen; Norway \\ Siegwart Lindenberg \\ Department of Sociology/ICS \\ University of Groningen \\ Grote Rozenstraat 31; 9712 TG Groningen \\ and
}

Tilburg Institute for Behavioral Economics (TIBER), Tilburg University, The Netherlands

Revised 31. October, 2011

Keywords: Teams, the theory of the firm, goal framing theory.

JEL Code: D23, L25, M1. 
TEAMS, TEAM MOTIVATION, AND THE THEORY OF THE FIRM

\begin{abstract}
A concern with teams was central to early attempts to grasp the nature of the firm, but fell out of favor in later work. We encourage a return to the emphasis on teams, but argue that the idea of teams as central to the nature of the firm needs to be grounded in an appreciation of the importance of We frames and group agency. We use converging insights from evolutionary anthropology, cognitive social psychology and work on team agency to develop such a grounding, and link it to the issues of the existence and boundaries of firms.
\end{abstract}




\section{INTRODUCTION: BRINGING TEAMS BACK INTO THE THEORY OF THE FIRM}

What is the nature of the firm? According to a once prominent stream of research in the economics of the firm (Alchian \& Demsetz, 1972; Holmström, 1982; Alchian, 1984; Kandel \& Lazear, 1992) the fundamental nature of the firm lies in "team production," specifically, in the firm being a team of heterogeneous, but complementary resources where precisely measuring the marginal product of each input factor is difficult. However, in the economics of the firm literature, the team production emphasis has largely been supplanted by an emphasis on specialized assets and investments and the under-investment threats and ex post haggling problems they may give rise to (Hart, 1995; Williamson, 1996).

In this article, we argue for a return to the emphasis on team production and management for team production as lying at the core of our attempts to understand why firms exist and what explains their boundaries and their internal organization. Teams are a basic form of human cooperation with an impressive evolutionary past. Recent work in management and economics broadly asserts that firms increasingly organize around teams of strongly complementary human resources (Lepak \& Snell, 1999). This is manifest in two ways. First, the boundaries of firms shrink so that the services of less strongly complementary resources are sourced from other firms (Rajan \& Zingales, 2000, 2001; Lippman \& Rumelt, 2003). Second, the basic organizational unit is increasingly becoming the team/project/group (rather than the department or division) (Zenger \& Hesterly, 1997). Thus, teams should be central in our attempts to understand the emerging nature of firms. However, we argue that the understanding of what teams are should to go substantially beyond the narrow understanding of the economics of the firm. We also argue that an understanding of teams informed by converging advances in the understanding of teams in fields and disciplines, such as management, psychology research, evolutionary anthropology and game theory (e.g., Sugden, 2000, 2003; Kozlowski \& Bell, 2003; Ilgen, Hollenbeck, Johnson, \& Jundt, 2005; Tomasello, Carpenter, Call, Behne, \& Moll, 
2005), has the potential to significantly further our understanding of the key issues in the theory of the firm.

The team production stream was an attempt to answer the key explananda in the theory of the firm, as defined by Coase (1937) concerning existence, boundaries and internal organization of firms The team production stream focused on team production because it served to highlight three fundamental features of the theory of the firm: 1) gains from trade stemming from complementarities among heterogeneous resources, 2) team technologies that may function as covers for moral hazard, and 3) governance mechanisms (specifically, a monitor-residual claimant) that internalize the externalities stemming from 2). In the pioneering contribution to this stream (i.e., Alchian \& Demsetz, 1972), Coase's explananda were addressed in terms of internalizing externalities from team production (the firm's existence), team production (which defined the scope/boundaries of the firm), and monitoring and residual claimancy in the context of a nexus of contracts (internal organization). Formal representations of these ideas utilize non-cooperative game theory in which, crucially and true to the original contributions (e.g., Alchian \& Demsetz, 1972), team members' strategies do not include the goals of other team members or indeed the team itself (Holmström, 1982; Kandel \& Lazear, 1992).

We revisit teams as an essential part of firm organization, but we do so from a perspective that is very different from the older team literature in economics. Fundamentally, the latter does not do justice to what it means to engage in productive activities in a team (Gold, 2005). In particular, economics approaches to teams neglect the fundamental fact that members of a well-functioning team are motivated to achieve a common goal and that they choose actions and activities in order to realize this goal (a point that is better captured in economics in Marschak and Radner [1972] team theory, as well as in management research, e.g., DeChurch \& Mesmer-Magnus, 2010). In situations where players have some degree of common interest and their strategies are strongly complementary, they may be primed to team-identify and adopt a We frame in their strategy choice (Bacharach, 
2006). Work in evolutionary anthropology suggests that human beings are especially equipped with cognitive and motivational faculties that are dedicated to such identification and to the framing of their strategy choices (Tomasello et al., 2005). Apparently, our social brains (Dunbar, 2003) contain a hardwired ability to recognize a situation one that involves team efforts, and to trigger the special motivational and cognitive faculties to participate in these efforts (cf. Sebanz, Bekkering \& Knoblich, 2006). However, motivation for such team-oriented efforts is highly precarious and a team situation may degenerate into the prisoners' dilemma predicted by Alchian and Demsetz (1972), indicating that the latter situation is a special case.

We argue that there are far-reaching implications of these ideas for our fundamental understanding of firms and other organizations (see also Lindenberg and Foss 2011). Specifically, these ideas speak directly to the issues of coordination and motivation that constitute the core of the economics of the firm. However, they are difficult to frame in the context of the established tools of economics and game theory. Accordingly, we explicate the differences between the notions of teams in the sense of Alchian and Demsetz (1972) and the understanding of teams in the sense of jointly working on the realization of common goals with a We frame and the specific motivation this entails. We call this motivation "team motivation," and see it as a subset of the broader set of pro-social motivations. ${ }^{1}$ We also discuss recent game theoretical ideas that seem fruitful for treating the latter in a more formal manner, mainly the ideas of Bacharach (2006) and Sugden (2000, 2003; Gold \& Sugden, 2007) as they pertain to team agency. We finally link these ideas to the classical questions in the theory of the firm, that is, the existence and boundaries of the firm. While markets are not necessarily inconsistent with conditions of cooperation in teams (Bruni \& Sugden, 2008), firms can generally provide conditions that are conducive to team motivation at lower cost. However, we argue that as firms grow, it becomes increasingly difficult to uphold the special motivation for cooperation in teams, so that there are limits to the scope and size of firms.

\footnotetext{
${ }^{1}$ Note that we divorce this entirely from ethical considerations. Thus, a group of mafia members may exhibit team motivation. Team motivation, also called "joint production motivation” (Lindenberg and Foss 2011) can apply to any kind of group that endeavors to realize common goals, legitimate or not.
} 


\section{TEAMS AND THE THEORY OF THE FIRM}

Two classical works on teams were published in 1972, namely Marschak and Radner's (1972) “team theory" approach and Alchian and Demsetz' (1972) emphasis on "team production." Both gave rise to different research streams within the then emerging economics of the firm, namely the team theoretical stream and what Williamson (1985) calls the "measurement approach" (roughly equal to agency theory).

These two contributions characterize teams very differently and identify very different problems of team organization. Thus, Marschak and Radner define a team as "an organization the members of which have only common interests" (1972: 9). They study “... the case in which several persons perform various tasks including those of gathering and communicating information and of making decisions; but they have common, not divergent, interests and beliefs. Hence the optimality requirement is easily defined, just as in the case of a single person. But the single person's problem of optimizing his information instrument and its use [i.e., non-cooperative game theory] is replaced by that of optimizing the allocation of tasks among the members of a team" (Marschak \& Radner, 1972: 4). Thus, team theory assumes that team members have common goals so that it is as if the team is maximizing its expected net payoff.

Alchian and Demsetz define teams indirectly, namely as a group of individuals who are engaged in "team production," that is, “... production in which 1) several types of resources are used and 2) the product is not a sum of separable outputs of each cooperating resource ... [and] ... 3) not all resources used in team production belong to one person" (Alchian \& Demsetz, 1972: 779). Team production involves super-additivities (or, "synergies"), and will be used when the productivity gains (relative to the "sum of separable production") can "cover the costs of organizing and disciplining team members." Famously, Alchian and Demsetz (1972) link minimizing these costs to the existence of a specialized monitor who assumes the role of residual claimant. Hence, the emergence of the "classical capitalist firm." The elegance of Alchian and Demsetz's explanation is that it 
simultaneously explains the existence, boundaries and internal organization of firms in exceedingly simple terms (too simple, as it turned out).

Marschak and Radner (1972) has enjoyed limited attention, in spite of some attempts to revitalize this research stream (e.g., Bolton \& Dewatripont, 1994). The theory of the firm became pre-occupied with incentive conflicts and their potential efficiency losses, and how such conflicts may be partly remedied by contractual and governance means (for a historical account, see Foss \& Klein, 2011). This left little or no room for the interest in the structure of common interest games that occupied Marschak and Radner. In contrast, the Alchian and Demsetz (1972) paper enjoyed massive initial attention, and is sometimes seen as the founding contribution to the "positivist" (as distinct from the "formalist") branch of agency theory (Jensen, 1983). While the paper is still seen as a classical and seminal contribution, its emphasis on moral hazard in a team production is, however, not regarded as a necessary ingredient in the theory of the firm. Alchian himself later explicitly denied that team-production "is a necessary ingredient in the theory of the firm" (Alchian, 1984; Alchian \& Woodward, 1987), and the original paper indeed suffers from a number of logical and explanatory shortcomings. ${ }^{2}$

Perhaps because the Marschak and Radner approach never became a major analytical force in the theory of the firm and the Alchian and Demsetz (1972) analysis was abandoned as a foundational part of the theory of the firm, the emphasis on teams largely disappeared from the focus of theorists of the firm. To be sure, these contributions are still cited, and empirical (e.g., Drago \& Garvey, 1997) and experimental work (Grosse, Putterman \& Rockenback, 2009) continues to be carried out, but the last major theoretical contributions on teams (in the Alchian \& Demsetz tradition) are Holmström (1982) and Kandel and Lazear (1992). ${ }^{3}$

\footnotetext{
${ }^{2}$ For example, there are shortcomings with respect to its treatment of authority (Williamson, 1985), its lack of applicability to diversified firms and its failure to explain why the monitor couldn't be an employee of a firm specialized in producing monitoring services (Hart \& Holmström, 1989).

${ }^{3}$ Holmström (1982) shows that in a team setting there is no sharing rule that can simultaneously satisfy the criteria of Nash equilibrium, Pareto optimality and budget balance. This "impossibility result" is used to explain the separation of ownership and control in the modern corporation.
} 
We propose a return to the concern with teams as critical in the context of human cooperation, including the theory of the firm (see also Lindenberg and Foss 2011). We accept Alchian and Demsetz' basic characterization of team production, that is, productive activity that involves heterogeneous but complementary resources, a high degree of task and outcome interdependence, and the potential for super-additive outcomes. We also accept Marschak and Radner's (1972) characterization of a team as a group of agents with a common goal that can only be achieved by an appropriate combination and coordination of the individual activities of the group members. However, we agree with Blair and Stout (1999: 267-8) that earlier analysis in economics has “... sidestepped some of the most interesting ... questions about teams, including: What are the sources of the economic surpluses in team production, and how can they best be harnessed and directed?"

As we shall argue addressing the "most interesting questions about teams" requires that we abandon the "non-cooperative" emphasis on individual utility maximization and moral hazard (whether or not it is tempered by invocations of "team spirit" [Alchian \& Demsetz, 1972] and "peer pressure," Lazear \& Kandel, 1992). But it also requires that we break with the team theory assumption that individuals in teams always have common goals. What is needed is the recognition that individuals may adopt team goals (intentions) or individual goals (intentions), and that what they adopt depends on the extent to which the relevant goals are prompted and maintained by the team itself or by circumstances outside of the team. In turn, recognizing this requires that we think of the possible precariousness of the adoption of team goals and thus also of the close interrelation between cognition and motivation, both of which aspects are virtually absent in extant research. To gain additional insight we need to take a look at what other fields, inside and outside of economics, have had to say about team production and its governance and organization (in a broad sense).

TEAMS: REASONING AND MOTIVATION

What Other Fields Tell Us About Cooperation in Teams 
Teams and team production are basic kinds of social organization that have existed since the first small hunting bands of homo sapiens roamed the savannas of Africa many millennia ago. Work in evolutionary anthropology suggests that evolution made groups of humans capable of overcoming the free-rider problem in a different way than that proposed by Alchian and Demsetz. The argument is that human beings are especially equipped with cognitive and motivational faculties that have evolved to facilitate participating in productive activities in teams (Tomasello et al., 2005). These faculties created the adaptive advantage of human beings living in larger groups, and the neocortex evolved as a "social brain" to allow primates and especially human beings to draw adaptive advantages from living in such groups (Dunbar, 2003).

Studies of perception and action in social contexts indicate that the brain contains an ability to perceive and recognize a situation as one that involves a team effort. Moreover, this recognition triggers specialized, coordinated cognitive faculties that are attuned "to make common cause" (Sebanz, Bekkering \& Knoblich, 2006). Thus, members of a team oriented towards team goals literally perceive the environment differently than in independent action: they recognize a team endeavor and see themselves as part of this endeavor, each with their own roles and responsibilities, involving a sharing of cognitions about the relevant tasks, interdependencies, timing, and possible obstacles to smooth coordination in terms of joint goals. They are able to mutually anticipate goalrelated actions from others and to cognitively coordinate temporal and special aspects of cooperation (Higgins \& Pittman 2008; Sebanz et al., 2006). They exert intelligent and adaptive efforts, and are willing to supply inducement and assistance to others to make them do their bit (Tomasello et al., 2005), and sanction them if they do not (Ostrom et al., 1992).

As Grosse, Putterman and Rockenbach (2009: 2) argue, the Alchian and Demsetz team situation is an example of the kind of problems that have been studied by experimental economists as public goods games. A general finding within this literature is that individuals voluntarily contribute to public goods (Zelmer, 2003), and incur costs to punish free riders (Fehr \& Gächter, 2000). The 
interpretation often is that individuals hold social preferences and derive utility from behaving prosocially (Fehr \& Falk, 2002). However, such preferences seem to be context-dependent (Tversky \& Simonson, 1993). Moreover, they seem insufficient to prevent decay of cooperation over time, unless they are supported by flanking arrangements (Ledyard, 1995).

Reviewing the evidence on game-theoretic studies of cooperation, Ledyard concluded that “... it is possible to provide an environment in which almost all of the subjects contribute toward the group interest. ... Why ... this all works remains a mystery" (Ledyard, 1995: 172). Apparently, situations exist that may somehow prime individuals to adopt group goals, and choose actions in terms of those goals. Those situations include contributing to public goods and choosing effort levels in a team production situation. However, as Ledyard suggests it is far from clear what is going on in terms of the dynamics of framing and motivation. Extant literature presents two (partly overlapping) explanations, namely team reasoning (Bacharach, 2006; Sugden, 2003; Gold \& Sugden, 2009) and goal-framing (Lindenberg, 1998, 2006). The first one highlights rational deliberation, while the other highlights bounded rationality and more automatic mental responses brought about by cues in the environment.

\section{What's Going On? Reasoning About What to Do In a Team}

Finding game-theoretical answer to Ledyard's question is made difficult by the fact that game theory and economics at large only take the team as a context for the realization of agent's own goals; thus, actions are never deliberated upon and chosen in terms of group goals. The main exception to this claim is represented by the work of Michael Bacharach (2006) and Robert Sugden (2000, 2003; Gold \& Sugden, 2009), partly drawing on earlier work by philosophers such as Gilbert (1999) and Tuomela (2005).

Bacharach's fundamental concern is with modes of practical reasoning, that is, reasoning that leads to prescriptions about what an agent should do, given what he seeks to achieve. The practical reasoning of standard game theory proceeds in terms of an "I frame" (Tuomela, 1995), framing each 
player as asking, "What should $I$ do in terms of strategy choice, given that $I$ wish to maximize $m y$ utility?" Bacharach developed a series of examples based-provocatively—on the "Hi-Lo game." This is an asymmetric common interest game (e.g., in the two player case, it may have $(2,2)$ and $(5,5)$ in the main diagonal and $(0,0)$ and $(0,0)$ in the other one).

Clearly, intuition (as well as theoretical argument, e.g., Crawford \& Haller, 1990) suggests that coordination on the Pareto optimal equilibrium is particularly trivial here; more so than in, for example, the closely related stag-hunt game. However, Bacharach argues that classical game theory is in general not capable of demonstrating-in terms of practical reasoning-how players can choose strategies that jointly lead to Pareto optimal outcome (rather than the Pareto-inferior one). Rather, classical game theory is concerned with consistency requirements. Thus, statements such as "if every player believes everyone else to choose actions that are consistent with equilibrium (somehow specified), then they have valid reasons to choose those actions" are not statements about the reasoning process that leads to those valid reasons, but statements about the end results of such processes. Bacharach's argumentative strategy seems to be that if individual reasoning leading to Iintentions cannot lead to the optimal outcome in the "obvious" situation of the Hi-Lo game, then this holds for more complicated games (e.g., the stag-hunt game) a fortiori.

Now, real-world players clearly have little difficulty finding the optimum outcome in Hi-Lo games (Crawford \& Haller, 1990). Bacharach's answer is that this is because real world players reasoning about games such as the Hi-Lo game, in fact, do not adopt reasoning that proceeds in term of I-intentions. On the contrary, they adopt what (Sugden, 2003) calls "team reasoning," adopting "team preferences" (Sugden, 2000), leading to the formation of a We frame. Team reasoning entails practical reasoning about what we should do as a group to further our goals. An important aspect of team reasoning as a mode of practical reasoning is that it generates action recommendations that are less conditional on what the individual believes about the actions (and reasons for actions) of other individuals (see Sugden [2000] and Bacharach [2006] for complications). Specifically, when a team 
adopts a We frame and engage in team reasoning, the underlying game form is transformed so that instead of having payoffs defined for each participating individual, there is a single scalar for any combination of strategies which represent the team payoff for this combination-which bridges the gap between practical reasoning and equilibrium outcomes.

The main part of the argument is the concern with valid reasoning from certain premises (i.e., the adoption of an I or a We frame). This is also the rational, deliberative part. Bacharach does not argue that the choice of a frame is an intentional act. Rather, he argues that the We frame is highly functional in certain situations and environments, and that it has been produced by evolutionary selection (forging a link to evolutionary anthropology). Certain features of a game prime individuals to adopt a We frame (Bacharach, 2006: 165-166). Specifically, priming factors are the degrees of "common interest" and "strong interdependence" in the game. Common interest ranges from zero sum games (in which there is zero common interest) to (symmetrical) coordination games in which there is no conflict of interests at all, and includes games with some conflicting interests (as in the battle-of-the-sexes game) (see also Zizzo \& Tan, 2009). Common interest will, however, only prime a We frame in a team if the team is currently in a less-preferred state, but is able to move the preferred state by means of team action. This will be the case when the game exhibits strong interdependence, so that only a combination of actions by team members will be able to realize the preferred state of the team.

Clearly, the PD game possesses the feature of common interests and strong interdependence. However, Bacharach does not naïvely claim that these features invariably leads to cooperation in the PD game. In in such a game “... players might see only, or most powerfully, the features of common interest and reciprocal interdependence which lie in the payoffs on the main diagonal. But they might see the problem in other ways. For example, someone might be struck by the thought that her coplayer is in a position to double-cross her by playing [defect] in the expectation that she will play 
[cooperate]. This perceived feature might inhibit group identification” (Bacharach, 2006: 169). The question when players will see the game in one way or another is left unanswered.

\section{What's Going On? Team Motivation and Goal Framing Theory}

Bacharach and Sugden's work on We and I frames, team reasoning and so on represent important strides forward in aligning our knowledge about teams in an evolutionary context with game theoretical thinking. However, it does less to identify the motivational mechanisms at work. In particular motivation seems entirely endogenous to cognition (e.g., adopting a We frame reframes the payoffs of a game) and, hence, not worthy of a distinct treatment. Moreover, the theory presents little detail about what may prompt changes between I and We frames. It seems to impose a strict either-or status of these frames; that is, a player is either fully in an I or a We frame, and there is apparently no recognition that one of these frames may be in the cognitive foreground while the other stays in the cognitive background. ${ }^{4} \mathrm{~A}$ further problem is that it does not explicitly treat the phenomenon that support for a We frame may decay unless it is scaffolded by extra arrangements (Andreoni, 1988; Fehr \& Gächter, 2002). Finally, Bacharach and Sugden do not seem to allow for the simultaneous existence in the mind of individuals of multiple goals.

In contrast, cognitive social psychology goes further with respect to identifying these crucial motivational details of the We frame and team agency. In particular, goal-framing theory is concerned with the motivational force of collective orientations, such as those implied by We frames and team reasoning. It suggests that there is a distinct kind of motivation that is particularly geared to collaborative activities in teams. How this works is explained by goal-framing theory (Lindenberg 2008, Lindenberg \& Foss, 2011). ${ }^{5}$

\footnotetext{
${ }^{4}$ However, Bacharach (2006) allows for "circumspect team reasoning" in an attempt to capture the possibility that some players may be in an I frame while others are in a We frame which analytically may have similar consequences.

${ }^{5}$ Such motivation is distinct from "pro-social motivation" (e.g., Penner, Dovidio, Piliavin \& Schroeder, 2005; Benabou \& Tirole, 2008) because the latter does not require that individuals interact in a team, adopting team reasoning. Sugden (2008: 402) hints at this when he criticizes one of the experiments in Colman, Pulford and Rose's (2008) for failing to discriminate between pro-social motivation and team reasoning.
} 
Goal-framing theory applies the insight from (social) cognition research that mental constructs have to be activated in order to affect behavior, and that goals are particularly important mental constructs in which cognitions and motivations are intricately intertwined (e.g., Förster, Liberman \& Higgins, 2005; Kruglanski \& Köpetz, 2009). There are also overarching goals, More concretely, gGoals, and particularly overarching goals, govern what we attend to (Posner \& Petersen, 1990); what concepts and what kinds of knowledge are being activated; what alternatives we consider; what information we are most sensitive about; what we expect others to do, and how we process information (Gollwitzer \& Bargh, 1996; Förster, Liberman \& Higgins, 2005; Kruglanski \& Köpetz, 2009). In turn, these cognitive processes have an impact on motivation by inhibiting other goals (Shah, Friedman \& Kruglanski, 2002); by influencing what we like and dislike (Ferguson \& Bargh, 2004); and by governing the criteria we use to judge goal realization or failure (Carver \& Scheier, 2002).

There are different overarching goals (Lindenberg and Steg 2007) and when they are focal (i.e., when they are activated at the moment), they "frame" a situation by steering important cognitive processes in their service. In their competition for the privilege of being focal (i.e., for being a "goalframe") they try to inhibit each other (Brewer, 2004). There are overarching goals concerning individual interests (hedonic and gain goals, see below). But, importantly, one overarching goal is connected to a supra-individual orientation, called a normative goal, and it may be characterized by the desire "to act appropriately" in the service of the supra-individual entity be that a dyad, group, organization, or nation (Moorman \& Blakely, 1995; Van Knippenberg, 2000). ${ }^{6}$ The criteria for goal fulfillment are linked to the realization of joint goals and to meeting joint appropriateness standards. When the normative goal is focal, the two competing individual interest goals are pushed into the cognitive background. This suspends opportunism to various degrees, as illustrated by the finding that people act very differently in terms of cooperation when they identify a situation (i.e., the exact

\footnotetext{
${ }^{6}$ Note that the normative goal frame has its dark side: It can stifle creativity and create Yes Men if there is no accountability and the normative goal frame supports sub-group egotism and thereby leads to fragmentastion (see Lindenberg \& Foss [2011] for details).
} 
same prisoners' dilemma game) as a "community game" or a "Wall Street game" (Liberman, Samuels \& Ross, 2004; see also Pillutla \& Chen, 1999).

There is a variant of the normative goal that is directed at cooperation in a team rather than just at a focus on appropriateness (norms) and/or collective identification and a feeling of We. Bacharach (2006) suggests that inherent features of the underlying game (e.g., strong interdependence) may be enough to bring this special team motivation about; however, as we will argue, more is needed to bring this motivation about and to maintain it. Importantly, the normative goal is easily pushed into the background by the individual interest goals, unless it is strongly supported by features in the environment (see Keizer, Lindenberg \& Steg 2008). Strong interdependence, though an important ingredient, is not sufficient to support the normative goal (let alone the team cooperation variant of the goal) against the competition of individual interest goals. What exactly are these competing goals?

One overarching individual interest goal, called the gain goal, is directed at maintaining or improving their resources (e.g., status and money). When it is focal, the criteria for goal realization pertain to improvements in these resources. A gain goal-frame makes individuals highly sensitive to opportunities for and threats to the improvement of their resources, and thus particularly sensitive to incentive instruments. For example, in such a goal-frame individuals will react strongly to advancement schemes, are willing to invest in education if returns are reasonably certain, will be competitive with regard to advancement, and may act opportunistically (Williamson, 1985). Since the normative goal is pushed into the background, group goals and norms are seen as constraints to be reckoned with when furthering one's own career, income, or status, rather than as guiding principles for appropriate action.

The other individual interest goal, called the hedonic goal, is directed at improvement of the way one feels at a particular moment, such as seeking direct improvement in self-esteem, seeking excitement, and avoiding unpleasant effort, negative thoughts and events, and uncertainty. The 
criteria for having realized the goal relate to improvements in the way one feels. The power of this goal-frame vis-à-vis rival goal-frames derives from its direct link to emotions (Ryan, Huta \& Deci, 2008). A hedonic goal-frame makes individuals oriented towards instant gratification in different domains. ${ }^{7}$ For example, if a particular cue makes a person hedonic with regard to one aspect (say having fun) the fact that it is an overarching goal will also make that person hedonic with respect to many other aspects (such as impatience in financial transactions). ${ }^{8}$

Both these individual interest goals are formidable competitors for the normative goal unless they can be harnessed to support the normative goal from the background. The recognition of this precariousness of the normative goal-frame may be the most important ingredient for understanding firms and other organizations emerging from goal framing theory. It has direct and concrete consequences for the way governance structures that create and maintain the motivation for cooperating in teams could possibly be constructed (Lindenberg \& Foss, 2011), but also for the theory of the firm itself.

\section{TEAMS AND THE EXISTENCE AND BOUNDARIES OF THE FIRM}

Bacharach (2006) explicitly wanted to examine the implications of his specific approach for the understanding of organizations, but unfortunately died before he could accomplish that task, and what is left from his hand does not go beyond team-theoretic (in the sense of Marschak \& Radner) considerations (e.g., see Bacharach, 2001). Lindenberg and Foss (2011) apply the insights from goal framing theory to governance structures, especially reward design and structural design (i.e., key aspects of the internal organization of firms). But they do not address the implications of this theory

\footnotetext{
${ }^{7}$ A recent experiment (Van den Bergh, Dewitte \& Warlop, 2008) illustrates this point. One group of (male) subjects was exposed to photographs of young women in bikinis, the other was not. Subsequently both groups were engaged in a completely different experimental task about impatience in monetary transactions. The exposure to the bikini women made subjects (at least temporarily) much more impatient in monetary transactions, even though the latter were not directly related to the former.

8 Goal framing theory focuses on the three substantive goals just described. Other overarching goals, such as approach/avoidance or leaning/performance goals found in the literature are not rival to this approach, but can differ within each one of the three goal-frames. There is no space to go into such ramifications in this paper.
} 
for the other aspects of the theory of the firm: the existence and boundaries. In the remainder of this article, we will address these issues.

The conventional approach in the economics of organization is to begin from potential gains to trade from transactions between independent parties, ask why these gains cannot be fully realized in the context of market organization, and tell a story about how shifting these transactions to a firm mode of organizations makes it possible to create joint surplus that cannot be realized under alternative governance structures. We will follow this explanatory heuristic in the following; specifically, we ask why only firms can succeed on a sustained basis in fully realizing the joint surplus that team motivation brings about.

Our claim that only the firm governance structure can succeed on a sustained basis in fully realizing the joint surplus that team motivation brings about is admittedly controversial. As Frey, Luethi and Osterloh (2011) show, "community enterprises" such as opensource software production and Wikipedia, are not firms, but are built on a high team motivation. However, the crucial difference between open source networks and firms is that in the latter, there is a fixed membership whereas in the former members self-select in and out. This means that for open source networks, the problem of overstretching the size of the team does not occur. What would create malfunctioning in the firm due to loss of team motivation in the conglomerate does not happen in the network due to flexible self-selection. The implication is that such networks can have a competitive advantage compared to fixed membership teams. But it also seems clear that they are not suited for every kind of jointly produced good.

Note also that we do not argue that firms always and everywhere arise to safeguard the particular motivation to engage in team-related activities and that this uniquely explains their boundaries. Rather, we assert that realizing the joint surplus that team motivation brings about provides one reason why firms exist and one explanation of their boundaries (other, complementary, reasons are economizing on bargaining costs [Coase, 1937; Wernerfelt, 1997] or protecting specific 
investments, Hart, 1995; Williamson, 1985). Not all firms necessarily realize team motivation. And firms with few obvious team features, such as conglomerates, certainly exist. Thus, firms can certainly exist although they are very poor at mobilizing and sustaining team motivation. However, we assert that such firms cannot reach the levels of joint surplus that are available to those firms that do succeed in mobilizing and sustaining team motivation (cf. also Osterloh \& Frey, 2001). For example, while conglomerates consists of, in some cases, thousands of heterogenous teams, and while productive conflict between competing teams can be imagined, such creative heterogeneity and competition thrive best when individuals are embedded in an overall team context with real input and output interdependencies between units. Conglomerates cannot as a rule provide such a context. Thus, our theory is as much a theory of successful firms as it is a theory of economic organization. To see this, we need to consider team motivation and its consequences in greater detail.

\section{Team Motivation and Its Consequences for Joint Surplus}

The introduction of team motivation casts the understanding of the surplus from team production in a novel light. Two issues need consideration, namely, first, the efficiency yardstick that is used in assessing surplus, and, second, the sources of the additional surplus that team motivation yields.

With respect to the first issue, the economics of the firm applies notions of first- and secondbest efficiency (Hart \& Holmström, 1989; Hart, 1995; Laffont \& Tirole, 2001). Such efficiency yardsticks are defined relative to given preferences. Framing seems to have no explicit role to play in thinking about efficiency. However, in terms of goal-framing theory, the economics of the firm in actuality assumes that individuals are always and everywhere in the gain-goal frame, and its contribution lies in unfolding the manifold consequences for our understanding of contracts and governance structures and mechanisms of this assumption. Notions of first and second-best are therefore always implicitly defined taking this goal-frame the one that obtains. The introduction of the normative goal-frame and its sustenance of team motivation changes the understanding of 
efficiency. Thus, the point is not that if employees hold a normative goal frames they are capable of reaching and sustaining the value maximizing outcome that is defined for a situation in which employees are in a gain goal-frame (as in repeated game approaches to organizations; e.g., Kreps, 1990). Rather, in the normative goal-frame they can reach payoffs that they cannot reach in a gain goal-frame, even with repeated games. What are the sources of this additional economic surplus?

Team motivation has beneficial organization-level consequences because it impacts the tasks that organizational members are willing to engage in; how much effort they will put into these tasks; and how they coordinate their actions. It is also associated with pro-social behaviors, such as spontaneous sharing of knowledge (De Dreu et al., 2008), which, in turn, may positively impact work productivity and innovation performance (Tsai, 2001). It involves the heedful interrelating that has been found to assist coordination in ambiguous situations (Weick \& Roberts, 1993) and to promote innovation performance (Dougherty \& Takacs, 2004). As it implies a partial suspension of moral hazard/opportunism, it reduces the need for costly control mechanisms (Podsakoff \& McKenzie, 1997). Coordination costs are reduced because team motivation implies that organizational members generate shared representations of actions and tasks in terms of joint goals, reducing the need for planning and formalization. Individual efforts are channeled towards the realization of common goals.

These are consequences of the normative goal-frame and the team motivation it may give rise to when individuals perceive a situation as one that has team characteristics. Because individuals who are in a normative goal frame engage in fundamentally pro-social activities that they do not engage in when in the gain goal frame (and may choose higher levels of effort), the first best under team motivation is higher than the first-best as described in economics of the firm. The difference may be called "team motivation rents," that is, those rents that arise when team members are in the normative compared to the gain goal frame. Because the theory of the firm assumes that individuals are always in the gain goal frame, it is too pessimistic with respect to what can be achieved by 
human cooperation. And it arguably also misses out on important aspects of what explains the emergence and boundaries of the firm (on internal organization, see Lindenberg \& Foss, 2011).

\section{The Existence of the Firm in the Light of Team motivation}

Explaining how firms emerge (i.e., what explains their existence) from the perspective of team reasoning and team motivation requires that we explain what we mean by a "firm." We here adopt the definition that a firm is "a coalition of interspecific resources owned in common and some generalized inputs, whose owners are paid, because of difficulty of output measurability according to some criteria other than directly measured marginal productivity, and the coalition is intended to increase the wealth of the owners of the inputs by producing salable outputs" (Alchian, 1984: 275). This is not only a commonsense definition, but also one that harmonizes with the team notion, because of its emphasis on the firm as a "coalition of interspecific resources ... and generalized inputs." It is also a definition which is sufficiently broad to also include, for example, partnerships because it avoids defining the firm in terms of the employment contract (in contrast to Coase, 1937).

We have already summarized Alchian and Demsetz' (1972) theory of why firms in this sense should arise from the "inseparability" feature of team production. As we have seen, their theory proceeds solely in terms of I intentions. In a pertinent discussion, Williamson (1985: 240) adds his focus on asset specificity to Alchian and Demsetz "separability" issue in order to highlight the importance of the zone of acceptance in employment contracts (an issue deliberately sidestepped as a non-issue by Alchian and Demsetz). Williamson describes a move from commercial contracts with separable inputs to employment contract with inseparable inputs, where procedures of internal organization, such as grievance procedures, job security, etc., keep the zone of acceptance intact. The need for such procedures, he says, is “...especially great where members of the team develop idiosyncratic working relationships with one another, in which case no single member can be replaced without having disruptive effects on the productivity of the unit. More complex teams in which mutual motivation and internal monitoring are encouraged are apt to take shape in such 
circumstances" (Williamson, 1985: 244). Williamson (1985: 247) also notes that the "...firm will engage in considerable social conditioning to help assure that employees understand and are dedicated to the purpose of the firm." In sum, the prediction is that transactions that are characterized by inseparability and a high degree of asset specificity are best matched with the dedicated governance machinery that firms are best able to realize.

We concur with this overall conclusion, but do so for reasons that differ from Williamson's. Williamson hints at the problem of how to establish and maintain team motivation, that is, the simultaneous cognitive and motivational coordination among actors, and suggests that firms may particular advantages in dealing with this. However, the specific measures that he argues that firms can uniquely leverage do not seem particularly compelling. For example, why exactly would grievance procedures and job security safeguard create and safeguard team motivation? The problem seems to be that Williamson's approach, like the economics of the firm in general, is fundamentally dyadic (i.e., the relations that are considered are those between the individual employee and the firm) and based on I intentions, and the measures he considers are dyadic ones. Thus, the recognition that team motivation (which Williamson would seem to recognize) requires a specialized structure does not appear in Williamson's work.

A reason why firms may arise, then, is because cooperating agents realize that sustaining team motivation and thus the rents from such motivation requires the deployment of organizational instruments that are dedicated to this task. ${ }^{9}$ In Alchian and Demsetz' (1972) original paper team production is associated with synergies (i.e., super-additivities) deriving from the underlying technology, but the resulting team production rents are threatened by the potential for shirking that

\footnotetext{
${ }^{9}$ This is obviously a functionalist account. However, it is possible to build causal-genetic accounts of the emergence of firms from a team motivation perspective. Thus, teams may form spontaneously, or they may be put together by an entrepreneur who perceives an opportunity in doing this (Harper, 2008). Bacharach (2006) suggests that the characteristics of common interest and strong interdependence (cf. our earlier discussion) are conducive to team reasoning, but by the same token they may be seen as conditions facilitating the emergence of teams (Harper, 2008: 618619). Indeed, as Bacharach (2006: 165-166) points out, these characteristics prompt “... the parties to see that they have action possibilities which provide joint agency possibilities which have possible outcomes of common interest ... Some actions only get conceived if one gets the idea of certain possible outcomes, and conversely."
} 
team production introduces, and require supporting arrangements in the form of the allocation of decision and income rights that characterize the "classical capitalist firm" (ibid.). While the rents from team motivation are conceptually distinct from team production rents, they, too, are fragile and need supporting arrangements. The fragility of team motivation synergies stems from the precariousness of the normative goal frame. Relative goal strength matters to what goals will come to dominate cognitive processes. Importantly, in the absence of supporting arrangements the normative goal-frame is the weakest of the three goal-frames. From an evolutionary point of view, it makes sense that hedonic goals and gain goals have a default priority as basic needs are expressed by hedonic goals and caring for one's own resources (i.e., the gain goal frame) is vital for adaptive advantages. The relative weakness of the normative goal can also be gleaned from the fact that even if the normative goal is focal at a given moment, it tends to decay quite quickly unless it is strengthened by supporting arrangements, such as positive and negative sanctions (Andreoni, 1988; Ledyard, 1995; Fehr \& Gächter, 2002). Thus, absent supporting arrangements, one of the two "individualistic" goals (hedonic and gain) is likely to displace the normative goal-frame. What are these supporting arrangements and why are they particularly likely to be associated with firms rather than markets (cf. Foss, 1996)?

Lindenberg and Foss (2011) point to organizational and work design, and argue that a first important condition is that clearly perceptible interdependences within and across team boundaries must be part of the attention structure of the firm (Ocasio, 1997). The clearer the common goals, the various roles in which individuals help to reach those goals, and the functional connections of tasks and goals between different levels of the firm, the easier it is for employees to develop and sustain team motivation. ${ }^{10}$ Even if common goals are specified in the task and team design, they must still be embedded in a shared sense of common direction and affect at the level of the firm. This will also help prevent subunit egoism. A suitable means for achieving a common direction is a vision and

\footnotetext{
${ }^{10}$ Note that although classical organization theory (e.g., March \& Simon, 1958) also stress the important coordinating role of shared knowledge and the importance of clear goal, this is not related to team motivation.
} 
mission statement, consensually supported by top management, that focuses on a common purpose rather than on operational goals that are appropriate for the task and team structure.

Employees need to be rewarded individually in a contingent manner so as to maintain their motivation to engage in certain activities. However, contingent rewards, such as status advancement and monetary rewards, can foster a gain goal frame. In turn, contingent hedonic rewards, such as enjoyable tasks and better offices, can foster a hedonic goal frame. In both cases, the normative goal frame will be weakened and and intelligent effort will be selectively driven by what leads to personal rewards (hedonic or gain) rather than by what contributes to the realization of common goals (Frey \& Oberholzer-Gee, 1997; Lindenberg, 2001; Meyer and Gupta 1994; Milgrom and Roberts 1988). Contingent rewards, particularly rewards that are modest enough to keep gain and hedonic goals in the background, are needed. Instruments such as financial (bonuses, extra pay), career (promotion), personal development (empowerment), symbolic (honors), or enjoyable task rewards; bigger offices; company cars; and expense accounts should remain modest (compared to noncontingent rewards) and should be explicitly given as recognition of one's contribution to cooperative efforts in the team. Negative sanctions (financial or symbolic) for not contributing are likely to be legitimate in a team context and will strengthen the normative goal frame, provided the behavior can be monitored correctly (Fehr \& Rockenbach, 2003). Recognition must still be linked to some kind of measurement, which is often difficult in team contexts (Alchian \& Demsetz, 1972). However, when organization and team design is calibrated to support team motivation, efforts will be more easily observable because goal setting, plans, and agreements provide multiple information sources on individual performance.

\section{The Boundaries of the Firm in the Light of Team Motivation}

A persistent theme in the explanation of firm boundaries has been that complementarities between actions or investments play a key role in shaping these boundaries. Thus, actions are highly complementary in Alchian and Demsetz' (1972) team production theory, and modern property rights 
theory (Hart, 1995) stress the importance of complementary investments. However, under market conditions virtually all sharing rules (Holmström, 1982) give rise to inefficient effort or investment levels. Firm boundaries and the structure of property rights they imply reflect attempts to maximize such efforts/investments.

In the team motivation view, complementarities are also crucial, but for a different reason than those stressed in the above theories. As we argued above, team motivation is bounded by the cognitive and motivational forces created a structure that is easily recognized as combining individual inputs and individual intelligent efforts in a synergistic manner. When firms get increasingly large, this unity will be lost due to the fact that the objective structure will be less integrated and especially because the subjective ability to perceive jointness is limited to clear structures of functional interdependence. Also, increasing informational distance, difficulties of maintaining commitments, and problems of calibrating incentives accompany the increase in the size of the firm. These problems mean that team motivation becomes increasingly difficult to uphold. Moreover, growth may be associated with a combination of common purpose rhetoric with simultaneous strategic shifts to gain goal-frame instruments (such as special bonuses and, for extra flexibility, selective withdrawal of measures that protect the employment contract). This does not only weaken the team motivation, it also amounts to selective intervention (which, as Williamson (1985) has observed, works with physical but not with human assets) (Foss, 2003).

\section{CONCLUSIONS}

We have proposed a return to the concern with teams that characterized the theory of the firm in its period of inception in the early 1970s. This is partly prompted by an observed return to teams as the core of firm organization. This is often argued to be driven by globalization and the liberalization of financial and other markets (which tend to shrink the boundaries of the firm; cf. Rajan \& Zingales, 2000, 2001), and by advances in information and telecommunication technologies, cost accounting and measurement (which makes teams and projects more viable inside the corporate boundaries; $\mathrm{cf}$. 
Zenger \& Hesterly, 1997), as well as by the increasing knowledge content in production (which tends to promote cooperative decision-making among groups of peers; cf. Adler \& Heckscher, 2006). However, recent advances in game theory, cognitive psychology, and evolutionary anthropology have highlighted this special motivation that, under the right conditions, may support cooperation in teams (Gold, 2005) and may contribute to the observed tendency for team-based organization. The integration of these ideas with the extant theory of the firm is a huge, but not forbidding, task. The main barrier is that the economics of the firm is formulated in terms of I intentions, whereas we have highlighted the importance of We intentions, and the specific kind of motivation that accompanies such intentions in a team setting. It is, however, possible to align this collective focus with much of the received theory of the firm, such as its focus on discriminating alignment (Williamson, 1985).

Thus, we proffer the construct of team motivation and argued that it provides novel insight into the "sources of the economic surpluses in team production, and how ... they best [can] be harnessed and directed" (Blair \& Stout, 1999: 267-8). This allowed us to sketch where a focus on team motivation advances our understanding of the existence and boundaries of the firm, namely by directing attention to the specific organizational arrangements that need to be deployed to safeguard team motivation rents. These arrangements cannot be supplied by the market, partly because authority is required to deploy and administer them, and partly because they are opposed to the focus on the gain goal-frame and the need for high-powered incentives that are necessary for the market (Williamson, 1985).

From a team motivation perspective, firms arise to safeguard team motivation and its attendant rents, and their boundaries reflect this. It is surely possible to interpret this in standard terms: although team motivation resides in individuals individual (Bacharach, 2006), it only works if it is simultaneously in all employees, and in a coordinated way. In order to achieve this, a specific organizational design is required. And the specific asset that needs protection is then the specific way in which the firm's organizational design supports team motivation. However, it is worth repeating 
that the economic theory of the firm has no role for team production, and therefore does not raise the issue of how organizations can be designed to sustain it. Firms that succeed in deploying the organizational flanking arrangements that call forth and sustain team motivation will create more value than those firms that do not. In other words, our theory is potentially a theory of heterogeneity and differential corporate success (which the extant theory of the firm is not).

\section{REFERENCES}

Heckscher, C. \& Adler, P.S. eds. The Firm as a Collaborative Community. Oxford: Oxford University Press,

Akerlof, G.A. \& Kranton, R. 2005. Identity and the economics of organization. Journal of Economic Perspectives, 19: 9-32.

Akerlof, G.A. \& Kranton, R. 2010. Identity Economics: How Our Identities Shape Our Work, Wages, and Well-Being. Princeton: Princeton University Press.

Alchian, A.A. 1984. Specificity, specialization and coalitions. Journal of Institutional and Theoretical Economics, 140: 34-49, and reprinted in Benjamin, D.K., ed. 2006. The Collected Works of Armen A. Alchian, Vol. 2: Property Rights and Economic Behavior. Indianapolis: Liberty Press.

Alchian, A.A. \& Demsetz, H. 1972. Production, information costs, and economic organization. American Economic Review, 62: 772-795.

Alchian, A.A. \& S. Woodward. 1987. Reflections on the theory of the firm. Journal of Institutional and Theoretical Economics, 143: 110-136.

Alper, S., Tjosvold, D. \& Law, K. S. 2000. Conflict management, efficacy, and performance in organizational teams. Personnel Psychology, 53: 625-642.

Amabile, T. M. 1993. Motivational synergy: Toward new conceptualizations of intrinsic and extrinsic motivation in the workplace. Human Resource Management Review, 3: 185-201.

Aumann, R. 1999. Interactive epistemology I: Knowledge. International Journal of Game Theory, 28: $263-300$

Aumann, R. \& A. Brandenburger. 1995. Epistemic conditions for Nash equilibrium. Econometrica, 63: 1161-1180.

Bacharach, M. 2001. Superagency: Beyond an Individualistic Game Theory. Mimeo for an Invited Lecture, Portignano, July 2001.

Bacharach M. 2006. Beyond individual choice: Teams and frames in game theory. Edited by N. Gold and R. Sugden. Princeton, N.J.: Princeton University Press

Baker, G., Gibbons, R. \& Murphy, K.J. 2002. Relational contracts and the theory of the firm. Quarterly Journal of Economics, 117: 39-84.

Barrett, H. C. \& Kurzban, R. 2006. Modularity in cognition: Framing the debate. Psychological Review, 113: 628-647.

Bénabou, R. \& Tirole, J. 2005. Incentives and prosocial behavior. National Bureau of Economic Research, Working Paper Series. 
Bernthal, P. R. \& Insko, C. A. 1993. Cohesiveness without groupthink. Group \& Organization Management, 18: 66-87.

Blair, M. \& Stout, L. 1999. A Team Production Theory of Corporate Law. Virginia Law Review, 85: 248-328.

Bolton, P. \& Dewatripont, M. 1994. The firm as a communication network. Quarterly Journal of Economics, 115: 809-839.

Bruni, L. \& Sugden, R. 2008. Fraternity: Why the market need not be a morally-free zone. Economics and Philosophy, 24: 35-64.

Carver, C.S. and Scheier, M.F. 2002. Control processes and self-organization as complementary principles underlying behavior. Personality and Social Psychology Review, 6: 304-315

Colman, A. M. and M Bacharach. 1997. Pay-off dominance and the Stackelberg heuristic. Theory and Decision, 43: 1-19.

Crawford, V.P. \& H. Haller. 1990. Learning how to cooperate: Optimal play in repeated coordination games. Econometrica, 58: 571-595.

DeChurch, L. A.; Mesmer-Magnus, J. R. 2010. The cognitive underpinnings of effective teamwork: A meta-analysis. Journal of Applied Psychology, 95: 32-53.

Deci, E. L. \& Ryan, R. M. 1985. Intrinsic Motivation and Self-determination in Human Behavior. New York: Plenum Press.

Deckop, J. R., Mangel, R. \& Cirka, C. C. 1999. Getting more than you pay for: Organizational citizenship behavior and pay-for-performance plans. Academy of Management Journal, 42: 420-428.

DeDreu, C.K.W. 2007. Cooperative outcome interdependence, task reflexivity, and team effectiveness: A motivated information processing perspective. Journal of Applied Psychology, 92, 628-638.

DeShon, R. P., Kozlowski, S. W. J.; Schmidt, A. M.; Milner, K. R.; Wiechmann, D. 2004. A multiple-goal, multilevel model of feedback effects on the regulation of individual and team performance. Journal of Applied Psychology, 89: 1035-1056.

DiMaggio, P.J. and Powell, W.W. 1991. Introduction. In W.W. Powell and P.J. DiMaggio (eds.), The New Institutionalism in Organizational Analysis. Chicago University Press: Chicago.

Drago, R. \& Garvey, G.T. 1998. Incentives for helping on the job: Theory and evidence. Journal of Labor Economics 16(1):1-25.

Dunbar, R.I.M. 2003. The social brain: Mind, language, and society in evolutionary perspective. Annual Review of Psychology, 32, 163-181.

Ellemers, N., de Gilder, D. \& Haslam, S. A. 2004. Motivating individuals and groups at work: A social identity perspective on leadership and group performance. Academy of Management Review, 29: 459-478.

Ellemers, N., de Gilder, D. \& van den Heuvel, H. 1998. Career-oriented versus team-oriented commitment and behavior at work. Journal of Applied Psychology, 83: 717-730.

Fehr, E. \& Falk, A. 2002. Psychological Foundations of Incentives. IZA Discussion Paper No. 507; CESifo Working Paper Series No. 714; Zurich IEER Working Paper No. 95

Fehr, E., Fischbacher, U. \& Kosfeld, M. 2005. Neuroeconomic foundations of trust and social preferences: Initial evidence. American Economic Review, 95: 346-351 
Fehr, E. \& Gächter, S. 2002. Altruistic punishment in humans. Nature, 415: 137-140.

Fehr, E. \& Rockenbach, B. 2003. Detrimental effects of sanctions on human altruism. Nature, 422: 137-140.

Foss, N.J. 1996. Knowledge-based Theories of the Firm: Some critical Comments. Organization Science, 7: 470-476.

Foss, N.J. 2003. Selective Intervention and Internal Hybrids: Interpreting and Learning From the Rise and Fall of the Oticon Spaghetti Organization. Organization Science, 14: 331-349.

Foss, N.J. \& Klein, P.G. 2011. Organizational governance. Mimeo.

Frey, B., R. Luethi \& M. Osterloh. 2011. Community enterprises: An institutional innovation. http://papers.ssrn.com/sol3/papers.cfm?abstract_id=1831123\#\#

Frey, B. S., \& Oberholzer-Gee, F. 1997. The cost of price incentives: An empirical analysis of motivation crowding-out. American Economic Review, 87: 746-755.

Fudenberg, D. \&Tirole, J. 1991. Game theory. MIT Press.

Förster, J., Liberman, N. \& Higgins, E.T. 2005. Accessibility from active and fulfilled goals. Journal of Experimental Social Psychology, 41: 220-239.

Gagné, M. \& Deci, E. L. 2005. Self-determination theory and work motivation. Journal of Organizational Behavior, 26: 331-362.

Gilbert, M. 1989. On Social Facts. London: Routledge.

Gold, N. 2005. Teamwork: Multidisciplinary Perspectives. New York: Palgrave.

Gold, N. \& Sugden, R. 2007. Collective Intentions and Team Agency. Journal of Philosophy,

Grosse, S., Putterman, L. \& Rockenbach, B. 2009. Monitoring in teams: Using laboratory experiments to study a theory of the firm. Journal of the European Economic Association (forthcoming).

Harper, D.A. 2008. Towards a theory of entrepreneurial teams. Journal of Business Venturing, 23: 613-626.

Hart, O. 1995. Firms, Contracts, and Financial Structure. Oxford: Oxford University Press.

Higgins, E.T. \& Pittman, T.S. 2008. Motives of the human animal: Comprehending, managing, and sharing inner states. Annual Review of Psychology, 59: 361-385

Holmström, B. 1979. Moral hazard and observability. Bell Journal of Economics, 10: 74-91.

Holmström, B. 1982. Moral Hazard in Teams. The Bell Journal of Economics, 13: 324-340.

Huber, G.P. \& Lewis, K. 2010. Cross-Understanding: Implications for Group cognition and performance. Academy of Management Review, 35: 6-26.

Ilgen, D.R., J.R. Hollenbeck, M. Johnson, \& D. Jundt, 2005. Teams in Organizations: From InputProcess-Output Models to IMOI Models. Annual Review of Psychology, 56: 517-543

Jensen, M.C. 1983. Organization Theory and Methodology. Accounting Review, 58: 319-339.

Kandel, E. \& Lazear, E.P. 1992. Peer pressure and partnerships. The Journal of Political Economy, 100: 801-817.

Kozlowski, S.W.J. \& B.S. Bell. 2003. Work Groups and Teams in Organizations. In I.B. Wiener, ed. Handbook of Psychology. Wiley. 
Kreps, D.M. 1990. Corporate culture and economic theory. In J. Alt \& K. Shepsle. Perspectives on Positive Political Economy. Cambridge: Cambridge University Press.

Kruglanski, A. W. \& Köpetz, C. 2009. What is so special (and non-special) about goals? A view from the cognitive perspective. In G. B. Moskowitz \& H. Grant eds. The Psychology of Goals: 27-55. New York: Guilford Press.

Ledyard, J.O. 1995. Public Goods: A Survey of Experimental Research.In Kagel, J. \& Roth, A. ed. Handbook of Experimental Economics. Princeton: Princeton University Pres

Lepak, D.P. \& Snell, S.A. 1999. The human resource architecture: Toward a theory of human capital allocation and development. Academy of Management Review, 24: 31-48.

Lindenberg, S. 2001. Intrinsic motivation in a new light. Kyklos, 54: 317-342.

Lindenberg, S. 2003. The cognitive side of governance. Research in the Sociology of Organizations, 20: 47-76.

Lindenberg, S. 2004. Myopia's price: inefficiencies in organizations. In A. Diekmann und T. Voss, (Eds.). Rational-Choice-Theorie in den Sozialwissenschaften: 217-229. München: Oldenbourg.

Lindenberg, S. 2006. Prosocial behavior, solidarity, and framing processes. In: D. Fetchenhauer, A. Flache, A.P. Buunk, \& S. Lindenberg (Eds.), Solidarity and Prosocial Behavior. An Integration of Sociological and Psychological Perspectives. (pp.23-44). New York: Springer.

Lindenberg, S. 2008. Social rationality, semi-modularity and goal-framing: What is it all about? Analyse und Kritik, 30: 669-687.

Lindenberg, S. \& Foss, N.J. 2011. Managing joint production motivation: The role of goal framing and governance mechanisms. Academy of Management Review.

Lindenberg, S. \& Steg, L. (2007), Normative, gain and hedonic goal frames guiding environmental behavior. Journal of Social Issues. 65(1) pp.117-137.

Lippman, S. A. \& Rumelt, R. P. 2003. A bargaining perspective on resource advantage. Strategic Management Journal, 24: 1069-1086.

March, J.G. \& H.A. Simon. 1958. Organizations. New York: Wiley.

Mathieu, J.E., Maynard, T. M., Rapp, T. \& Gilson. L. 2008. Team effectiveness 1997-2007: A review of recent advancements and a glimpse into the future. Journal of Management, 34: 410-476

Mathieu, J.E. \& Rapp, T.L. 2009. Laying the foundation for successful team performance trajectories: The roles of team charters and performance strategies. Journal of Applied Psychology, 94: 90-103

Mathieu, J.E., Rapp, T.L., Maynard, M.T., \& Mangos, P.M. 2010. Interactive Effects of Team and Task Shared Mental Models as Related to Air Traffic Controllers' Collective Efficacy and Effectiveness. Human Performance, 23: 22-40.

Meyer, M. W., \& Gupta, V. 1994. The performance paradox. Research in Organizational Behavior, 16, 309-369.

Milgrom, Paul R. and John Roberts 1988. An Economic approach to influence activities in organizations. American Journal of Sociology, 94:S154-179. 
Ocasio, W. 1997. Towards an attention-based theory of the firm. Strategic Management Journal, 18: 187-207.

Osterloh, M. \& Frey, B. 2000. Motivation, knowledge transfer and organizational form. Organization Science, 11: 538-550.

Ostrom, E., Walker, J. and Gardner, R., 1992. Covenants with and without a sword: self-governance is possible. American Political Science Review, 86: 404-417.

Penner, L. A., Dovidio, J.F., Piliavin, J.A. \& Schroeder, D.A. 2005. Prosocial behavior: Multilevel perspectives. Annual Review of Psychology, 56: 365-392.

Pillutla, M.M. \& Chen, X.P. 1999. Social norms and cooperation in social dilemmas: The effects of context and feedback. Organizational Behavior and Human Decision Processes, 78: 81-103.

Posner, M.I. \& Petersen, S.E. 1990. The attention system of the human brain. Annual Review of Neuroscience, 13: 25-42.

Rajan, R. \& L. Zingales. 2000. The governance of the new enterprise. In X. Vives, ed. Corporate Governance: Theoretical and Empirical Perspectives. Cambridge: Cambridge University Press.

Rajan, R. \& L. Zingales. 2001. The influence of the financial revolution on the nature of firms. American Economic Review, 91 (Papers and Proceedings): 206-11.

Ryan, R. M., Huta, V., \& Deci, E. L. 2008. Living well: A self-determination theory perspective on eudaimonia. Journal of Happiness Studies, 9: 139-170.

Scott, W.R. 1995. Institutions and Organizations. Sage: Thousand Oaks

Sebanz, N., Bekkering, H., \& Knoblich, G. 2006. Joint action: bodies and minds moving together. TRENDS in Cognitive Science, 10: 70-76.

Stewart, G.L. 2006. A meta-analytic review of relationships between team design features and team performance. Journal of Management, 32: 29-54.

Sugden, R. 2000. Team preferences. Economics and Philosophy, 16:175-204.

Sugden, R. 2003. The logic of team reasoning. Philosophical Explorations, 6: 165-181.

Sugden, R. 2008. Nash equilibrium, team reasoning, and cognitive hierarchy theory. Acta Psychologica, 128: 409-412.

Tomasello, M., Carpenter, M., Call, J., Behne, T., \& Moll, H. 2005. Understanding and sharing intentions: The origin of cultural cognition. Behavioral and Brain Sciences, 28: 675-735.

Tuomela, R. 1995. The Importance of Us: A Philosophical Study of Basic Social Notions, Stanford: Stanford University Press.

Tversky, A. and Simonson, I. 1993. Context-dependent preferences. Management Science, 39: 1179-1189.

Weick, K. E., \& Roberts, K. 1993. Collective mind in organizations: Heedful interrelating on flight decks. Administrative Science Quarterly, 38: 357-381.

Wernerfelt, B. 1997. On the nature and scope of the firm: An adjustment-cost theory. Journal of Business, 70:

Williamson, O.E. 1985. The Economic Institutions of Capitalism. New York: The Free Press. 
Zelmer, J. 2003. Linear Public Goods Experiments: A Meta-Analysis. Experimental Economics, 6: 299-310.

Zenger, T. \& Nickerson, J. 1997. The Disaggregation of Corporations: Selective Intervention, HighPowered Incentives, and Molecular Organizations. Organization Science 8: 209-222.

Zizzo, J.Z. \& Tan, J.H.W. 2009. Game harmony: A behavioral approach to predicting cooperation in games. International Center for Behavioral Business Research Working Paper, No. 2009_04. 